\title{
Comparison of Cantilever, Heart Loop and Circular Bending Test Methods in Determining the Bending Behaviours of Sewn Woven Polyester Fabrics
}

\author{
Sukran KARA iD 0000-0001-8866-2129
}

Dokuz Eyul University / Engineering Faculty / Textile Engineering Department / T1naztepe Campus, Buca, Izmir, Turkey

Corresponding Author: Sukran KARA, sukran.kara@deu.edu.tr

\begin{abstract}
Fabrics are cut and sewn to form 3-dimensional end-products. Bending rigidity is one of the properties that should be interpreted for sewn fabrics as it can affect drape, appearance and sensorial comfort of a garment. In the literature, there are several methods to measure the bending behaviours of fabrics. Parallelly, a variety of tests were employed for bending rigidity of sewn samples but their comparability for sewn samples are not known. In this study, 3 simple and standard test methods were used to compare the bending behaviours of fabrics with plied edge seams. For the tests, a sample set was prepared by using plain and twill woven polyester fabrics those were suitable for casual wear and sportswear. The fabrics were sewn with 3 different stitch types using 2 different stitch densities. Analysis results showed that, circular bend method had no or low correlation with cantilever and heart loop methods. Also any difference between the different types of sewn samples could not be detected by this method. In contrast, results of cantilever and heart loop methods showed low to moderate positive correlations for the bending lentghs and bending rigidities of samples.
\end{abstract}

\section{ARTICLE HISTORY}

Received: 04.06.2020

Accepted: 26.05.2021

\section{KEYWORDS}

Sewn fabric, bending behaviour, cantilever method, heart loop method, circular bending

\section{INTRODUCTION}

Fabrics are assembled together to form three dimensional textile products such as garments, upholsteries and technical textiles. The most common technique in assembling fabrics is stitching with a needle and sewing thread. The other but less used techniques consist of welding, bonding and pressing $[1,2]$.

When compared to two-dimensional planar fabric, a sewn article always shows different properties in terms of strength, appearance, drape, bending etc. This is caused because of cutting the fabric according to patterns and sewing it with respect to the models. This results with property discontinuities along the seam lines. On the other hand, even sewing the same fabric, the properties may change according to the sewing variables such as stitching type, stitch density, seam direction, sewing thread properties, thread tensions etc. $[2,3]$. Therefore, in the literature, there are many studies searching the effects of sewing parameters. Most of these studies focused on the seam strength and slippage of sewn fabrics [4-21].

In addition to the seam strength and seam slippage, there are other quality components of a sewn fabric such as bending rigidity, seam puckering and resistance to abrasion $[1,2]$. Among all these properties, bending behaviour has a different importance for a sewn fabric, as it affects both the quality, drape [2,22] and appearance [3]. A seam with a low bending rigidity is accepted as a more draped and softer seam. It can take form easier and affect the appearance positively [1]. However, from the literature, it is

To cite this article: Kara S. 2021. Comparison of Cantilever, Heart Loop and Circular Bending Test Methods in Determining the Bending Behaviours of Sewn Woven Polyester Fabrics. Tekstil ve Konfeksiyon, 31(2), 82-90. 
known that sewing increases the bending rigidity of the fabric, importantly [23, 24]. Bending rigidity of sewn fabrics were studied in the literature, in which the effects of stitch density [24, 25], sewing thread type [24], sewing needle fineness [5], sewing thread tension [5], seam allowance [24, 26, 27], seam placement [27], seam direction [23, 28], fabric thickness [26] and fabric type [25, 27] were determined. When the literature is analysed in details, it can be said that, different methods such as cantilever based methods (Shirley, Flexometer, FAST (Fabric Assurance through Simple Testing) instruments) [24-27, 29], heart loop method [23] and KES-F (Kawabata's Evaluation System of Fabrics) [28, 30] were employed to determine the bending lengths and bending rigidities of sewn samples. In addition, there is a variety of test methods, which were used to determine the bending behaviour of unsewn fabrics [31-33]. Despite the fact that there is a continuous popularity of comparative studies on different bending test methods for unsewn fabrics [34-42] till the first development of fabric bending measurement by Pierce in 1930 [43], according to the knowledge of the author, any studies have not been performed to compare the results of bending rigidites of sewn fabrics obtained by different test methods.

Apart from the unsewn fabrics, comparison of bending test methods for sewn fabrics is also essential. Because, when a fabric is sewn from its edge with another one, a multilayer structure forms along the seam line. This makes an extra thickness when compared to flat, one ply fabric. Both this increased thickness and plied structure of the seam can lead to differences in different bending tests and cause misreadings. Therefore, within the context of this study, a set of samples were formed by stitching woven polyester fabrics with different parameters and tested for their bending rigidities to compare the results for cantilever, heart loop and circular bend methods. These methods were selected as all cantilever, heart loop and circular bending methods are standard methods and applicable without complex and expensive test devices. Also, there is not any study in the literature comparing all these three simple methods together, even for unsewn fabrics. The correlations between different test results were determined to compare the methods. For this study, woven polyester fabrics those were suitable for casual and sportswear were used as the base fabrics. The results of this study may contribute to the research studies in this field and may be benefical for the quality control tests of ready-wear companies.

\section{MATERIALS AND METHODS}

\subsection{Materials}

Materials of this study were polyester sewing thread (PET) and woven polyester fabrics with plain and twill weaves. Sewing thread was a 3-ply $100 \%$ PET yarn with 120 ticket number. Properties of woven fabrics are given in Table 1.

\subsection{Methods}

\subsubsection{Sewing of samples}

Sewn samples and reference samples without stitches were prepared and tested for their bending rigidities. For sewing; lock stitch (stitch type 301, 2 yarn), 3-yarn overlock stitch (stitch type 504, 3 yarn) and 5-yarn overlock stitch (stitch type 516, 5 yarn) were used. These stitches were selected as they are used widely for garment production, especially for edge finishing and side seaming of woven fabrics. Samples were sewn with 3 and 5 stitches/cm stitch densities.

The seam preparation for lock stitched, 3-yarn overlock stitched and 5-yarn overlock stitched samples are shown in Table 2. Firstly, 2 plies of fabrics were sewn together from one of their longer edges. The seam allowances were $8 \mathrm{~mm}$ for lock stitched and 5-yarn overlock stitched samples, and $4 \mathrm{~mm}$ for 3-yarn overlocked stitched samples. After sewing, the fabric plies were opened as shown in the bottom row of Table 2. The seam allowances were folded in the back side of fabric (Figure 1.a), and the samples were ironed. A 3-ply structure was formed along the seam lines containing the base fabric and seam allowances. After sewing and ironing, the samples were cut in the desired dimensions according to standards, to leave the seam lines in the middle of the samples along the longer edges. The test directions and seam replacements on samples are given in Figure 1.b.

Before testing, all the samples were conditioned at standard atmosphere conditions $\left(20 \pm 2 \quad{ }^{\circ} \mathrm{C}\right.$ temperature, $65 \pm 5 \%$ relative humudity). To eliminate the tension differences those might occur on the ends of the sewn samples, samples were prepared $10 \mathrm{~cm}$ longer than the last dimensions and cut from each ends before testing. Experimental design and sample codes are given in Figure 2.

Table 1. Fabric structural properties

\begin{tabular}{|c|c|c|c|c|c|c|c|c|c|c|}
\hline $\begin{array}{l}\text { Fabric } \\
\text { type }\end{array}$ & Weave & $\begin{array}{c}\text { Unit } \\
\text { mass } \\
\left(\mathrm{g} / \mathrm{m}^{2}\right)\end{array}$ & $\begin{array}{c}\text { Thickness } \\
\text { (mm) }\end{array}$ & $\begin{array}{c}\text { Warp } \\
\text { density } \\
\text { (warp/cm) }\end{array}$ & $\begin{array}{c}\text { Weft } \\
\text { density } \\
\text { (weft/cm) }\end{array}$ & $\begin{array}{c}\text { Warp } \\
\text { count } \\
\text { (denier) }\end{array}$ & $\begin{array}{c}\text { Weft } \\
\text { count } \\
\text { (denier) }\end{array}$ & $\begin{array}{l}\text { Warp } \\
\text { twist } \\
(\text { tpm) }\end{array}$ & $\begin{array}{l}\text { Weft } \\
\text { twist } \\
\text { (tpm) }\end{array}$ & Yarn type \\
\hline $\begin{array}{l}\text { Plain } \\
\text { weave }\end{array}$ & Plain & 82 & 0.24 & 80.2 & 32.7 & 50 & 75 & 600 & 1200 & $\begin{array}{l}\text { Multifilamen } \\
\mathrm{t}\end{array}$ \\
\hline $\begin{array}{l}\text { Twill } \\
\text { weave }\end{array}$ & $\begin{array}{l}3 / 2 \text { right } \\
\text { hand twill }\end{array}$ & 93 & 0.32 & 82.0 & 43.5 & 50 & 75 & 600 & 1200 & $\underset{t}{\text { Multifilamen }}$ \\
\hline
\end{tabular}


Table 2. Formation of stitches

\begin{tabular}{|c|c|c|c|}
\hline STITCH TYPE & LOCK STITCH & 3-YARN OVERLOCK STITCH & $\begin{array}{c}\text { 5-YARN OVERLOCK } \\
\text { STITCH }\end{array}$ \\
\hline $\begin{array}{l}\text { Cutway view of seam } \\
\text { (2-ply fabric and seam } \\
\text { along one of the long } \\
\text { edges) }\end{array}$ & $\mid \begin{array}{c}\text { Seam } \\
\text { allowance }\end{array}$ & $\mid \begin{array}{c}4 \mathrm{~mm} \\
\text { Seam } \\
\text { allowance }\end{array}$ & $\mid$\begin{tabular}{c|c} 
Seam \\
allowance
\end{tabular} \\
\hline $\begin{array}{l}\text { Cutway view of seam } \\
\text { (Open seam) }\end{array}$ & & 듬 & 풀 \\
\hline
\end{tabular}
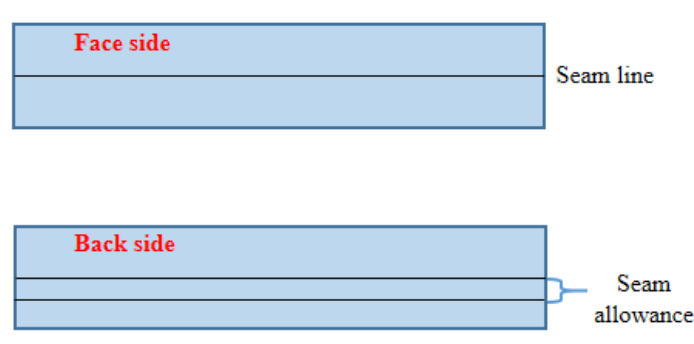

(a)

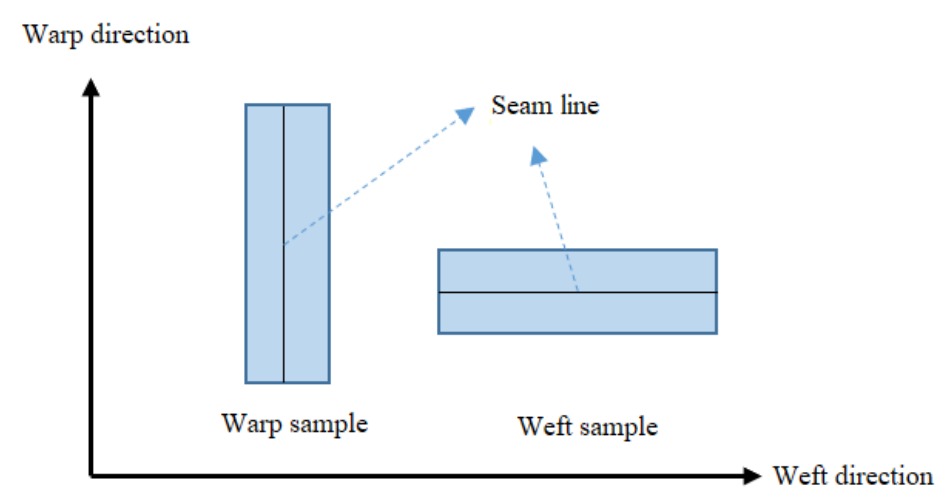

(b)

Figure 1. Schematics of sewn samples a) Face and back side views of samples, b) Test directions and seam directions

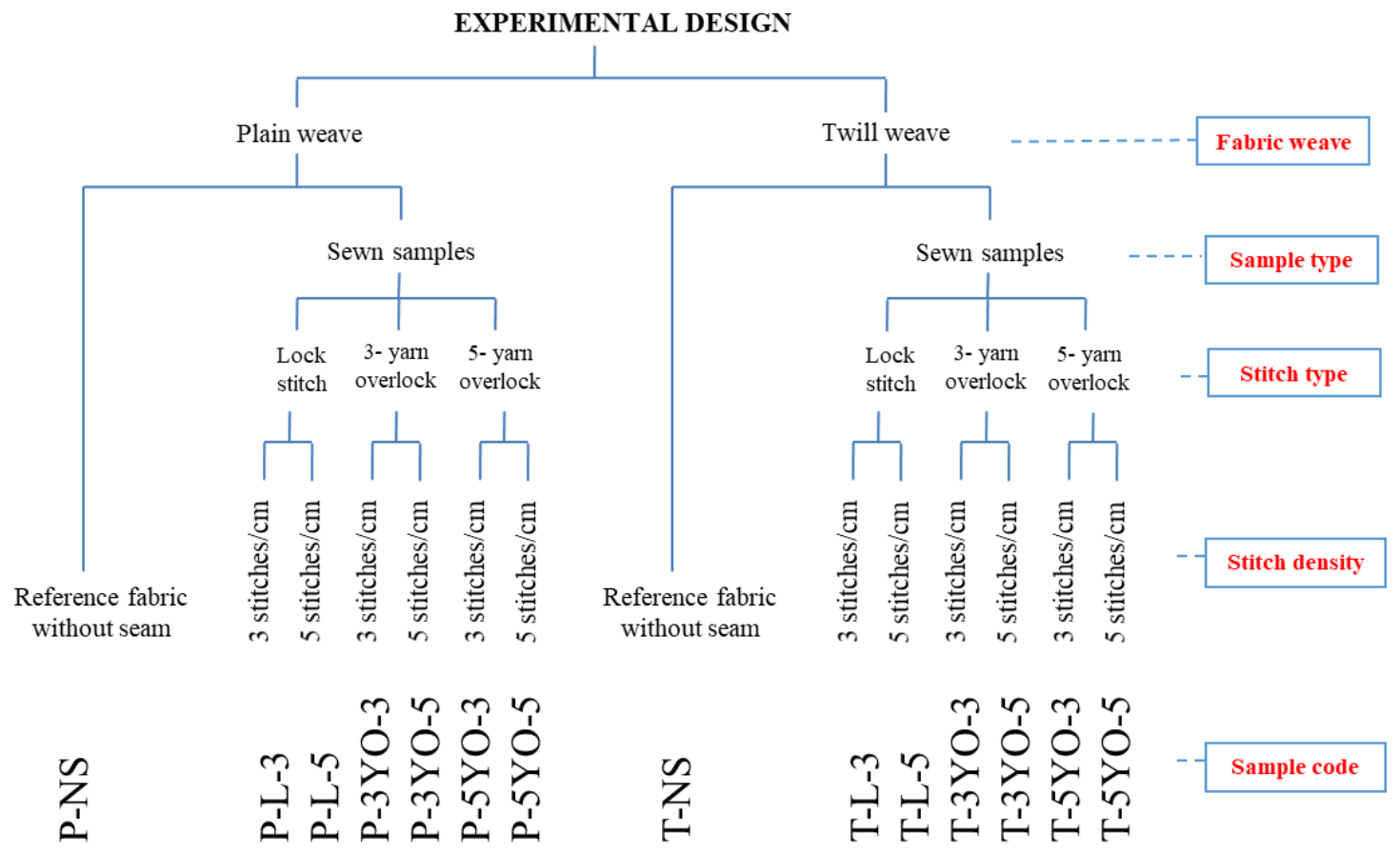

Figure 2. Experimental design of samples and sample codes 


\subsubsection{Cantilever method}

Cantilever method is probably the most preferred bending rigidity measurement method for woven fabrics as it is very simple to apply. In this study, sewn samples, which were prepared according to Part 2.2.1, were cut in the dimensions of $2.5 \mathrm{~cm}$ x $20 \mathrm{~cm}$. The test was performed according to ASTM D 1388- 18, Option A [44]. Samples were slid on a platform until their leading edges projected from the edge of a horizontal surface and made a $41.5^{\circ}$ angle with the horizontal. The length of the overhang was measured. The test was repeated for the face and back of both ends of each specimen. 5 samples were tested for each type of sewn fabrics. Bending length (c) and bending rigidity $(\mathrm{G})$ of samples were determined using overhang length $(O)$ values according to Equations (1) and (2).

$\mathrm{c}=O / 2$

$\mathrm{G}=1.421 \cdot 10^{-5} \cdot \mathrm{W} \cdot \mathrm{c}^{3}[\mu$ joule $/ \mathrm{m}]$

(c: bending length $(\mathrm{mm})$, w: fabric unit mass $\left(\mathrm{g} / \mathrm{m}^{2}\right)$ )

\subsubsection{Heart loop method}

Heart loop method is preferred for the samples, which are unsuitable for cantilever method, which tend to curl or twist, as it is harder to apply. In this method, sewn samples were cut to $2.5 \mathrm{~cm}$ x $25 \mathrm{~cm}$ dimensions and fastened to 2.5 $\mathrm{cm}$ wide bars before the test. Therefore, test dimensions were $2.5 \mathrm{~cm} \times 20 \mathrm{~cm}$. A heart shaped loop was formed according to the standard (ASTM D 1388-18, Option B [44]) and hung vertically under its own mass. The length of the hung loop was measured. Two measurements were taken for each sample, one from the face and one from the back side of samples. Measured loop lengths were used to calculate the bending lengths and bending rigidities of samples according to Equations (3) - (6) [44, 45]. For each stitching type, 5 samples were tested.

$\mathrm{G}=1.421 \cdot 10^{-5} \cdot \mathrm{w} \cdot \mathrm{c}^{3}[\mu \mathrm{joule} / \mathrm{m}]$

$\mathrm{c}=0.1337 \mathrm{~L} \cdot \mathrm{f}_{2}(\theta)[\mathrm{cm}]$

$\mathrm{f}_{2}(\theta)=(\cos \theta / \tan \theta)^{1 / 3}$

$\theta=32.85 \cdot((l-0.1337 \mathrm{~L}) /(0.1337 \mathrm{~L}))\left[^{\circ}\right]$

(L: strip length $(\mathrm{cm})$ and $l$ : loop length $(\mathrm{cm})$ )

\subsubsection{Circular bend method}

Circular bending method is a simple method that can be applied to all kind of woven, knitted or nonwoven fabrics. The principal of the circular bend method is to force a flat, folded swatch of fabric through an orifice in a platform and record the maximum force to push the fabric as an indicator of fabric bending rigidity. In this method, the measured force simultaneously averages the stiffness in all directions.

For this test, sewn samples were prepared both in warp and weft directions with the dimensions of $10.2 \mathrm{~cm} \times 20.4 \mathrm{~cm}$. Seam placements on samples were arranged according to Figure1.b, for warp and weft samples. Before the tests, samples were laid face down and folded to form a square of $10.2 \mathrm{~cm} \times 10.2 \mathrm{~cm}$. Then they were slightly compressed to flatten the crease. Afterwards, the samples were placed on the device and forced through the orifice. Maximum force was recorded for each sample to indicate the sample stiffness (ASTM D4032-08 [46]). For each type of sewn sample, 5 measurements were taken according to standard.

\subsubsection{Statistical analysis}

SPSS Package Program version 22 was used to make statistical comparisons between different sample types and different test methods. Firstly, normality tests were performed by considering Shapiro-Wilk and KolmogorovSmirnov tests, histograms, variation coefficients (\%), Skewness/Kurtosis values and Q-Q plots. For normally distributed data, One-way ANOVA and Pearson correlation coefficients were interpereted. For data, which were notnormally distributed, Kruskal-Wallis and Spearman's correlation coefficients were used. For normally distributed data, Tukey and Games-Howell tests were used as Post-Hoc tests, for homogeneous and non-homogenous data, respectively. For not-normally distributed data, Mann Whitney U test was performed.

\section{RESULTS AND DISCUSSION}

\subsection{Comparison of bending length results}

Bending length of samples were determined in cantilever and heart loop methods. In Table 3, bending lengths in both methods for warp and weft directions are given with standart deviation values. Also in Figure 3, the data are visualized. According to results, for both plain and twill fabrics, unsewn samples showed the lowest bending length values in warp and weft directions regardless of test method (Sig. values < 0.05). For sewn samples, smaller bending lengths were obtained in heart loop method when compared to cantilever results. This was valid in both warp and weft directions. In warp direction, bending lengths of 5 stitch densities were higher for cantilever method. A similar result was obtained in the literature for sewn plain fabrics in cantilever method [24]. The same trend was not observed in heart loop method. Statistical analysis showed that stitch density did not have any significant effects on the bending lengths of samples, except than the bending lengths of plain fabric samples measured in cantilever method. In addition, only the bending lengths of 5-yarn overlock stitched samples were significantly higher when compared to other stitch types, almost for all plain and twill samples sewn in warp and weft directions (Sig. values < 0.05). 
Table 3. Bending length results of cantilever and heart loop methods

\begin{tabular}{|c|c|c|c|c|c|c|}
\hline \multirow[b]{2}{*}{ Fabric type } & \multirow[b]{2}{*}{ Stitch type } & \multirow[b]{2}{*}{ Sample code } & \multicolumn{2}{|c|}{ Cantilever Test Results (cm) } & \multicolumn{2}{|c|}{ Heart Loop Test Results (cm) } \\
\hline & & & $\begin{array}{c}\text { Warp Mean } \\
\text { (St. Dev.) }\end{array}$ & $\begin{array}{c}\text { Weft Mean } \\
\text { (St. Dev.) }\end{array}$ & $\begin{array}{c}\text { Warp Mean } \\
\text { (St. Dev.) }\end{array}$ & $\begin{array}{l}\text { Weft Mean } \\
\text { (St. Dev.) }\end{array}$ \\
\hline \multirow{7}{*}{ Plain weave } & Unsewn & P-NS & $1.42(0.13)$ & $1.43(0.02)$ & $1.36(0.04)$ & $1.41(0.04)$ \\
\hline & \multirow{2}{*}{ Lock stitch } & P-L-3 & $2.69(0.07)$ & $2.62(0.15)$ & $1.88(0.05)$ & $2.04(0.13)$ \\
\hline & & P-L-5 & $2.75(0.07)$ & $3.07(0.07)$ & $1.81(0.04)$ & $2.12(0.09)$ \\
\hline & \multirow{2}{*}{$\begin{array}{l}\text { 3-yarn } \\
\text { overlock stitch }\end{array}$} & P-3YO-3 & $2.36(0.09)$ & $2.66(0.10)$ & $1.93(0.03)$ & $2.17(0.10)$ \\
\hline & & P-3YO-5 & $2.74(0.05)$ & $2.94(0.07)$ & $1.96(0.08)$ & $2.08(0.06)$ \\
\hline & \multirow{2}{*}{$\begin{array}{l}5 \text {-yarn } \\
\text { overlock stitch }\end{array}$} & P-5YO-3 & $2.76(0.13)$ & $3.04(0.07)$ & $2.07(0.06)$ & $2.26(0.13)$ \\
\hline & & P-5YO-5 & $2.89(0.17)$ & $3.31(0.14)$ & $2.03(0.06)$ & $2.27(0.03)$ \\
\hline \multirow{7}{*}{ Twill weave } & Unsewn & T-NS & $1.44(0.04)$ & $1.19(0.02)$ & $1.25(0.04)$ & $1.34(0.04)$ \\
\hline & \multirow{2}{*}{ Lock stitch } & T-L-3 & $2.56(0.06)$ & $2.49(0.12)$ & $1.70(0.03)$ & $2.01(0.01)$ \\
\hline & & T-L-5 & $2.52(0.10)$ & $2.85(0.17)$ & $1.81(0.01)$ & $2.03(0.06)$ \\
\hline & \multirow{2}{*}{$\begin{array}{l}\text { 3-yarn } \\
\text { overlock stitch }\end{array}$} & T-3YO-3 & $2.31(0.15)$ & $2.51(0.14)$ & $1.81(0.06)$ & $2.05(0.07)$ \\
\hline & & T-3YO-5 & $2.44(0.06)$ & $3.03(0.08)$ & $1.79(0.07)$ & $1.97(0.05)$ \\
\hline & \multirow{2}{*}{$\begin{array}{l}\text { 5-yarn } \\
\text { overlock stitch }\end{array}$} & T-5YO-3 & $2.65(0.25)$ & $2.94(0.10)$ & $1.95(0.06)$ & $2.11(0.10)$ \\
\hline & & T-5YO-5 & $2.87(0.06)$ & $2.86(0.17)$ & $2.01(0.11)$ & $2.34(0.08)$ \\
\hline
\end{tabular}

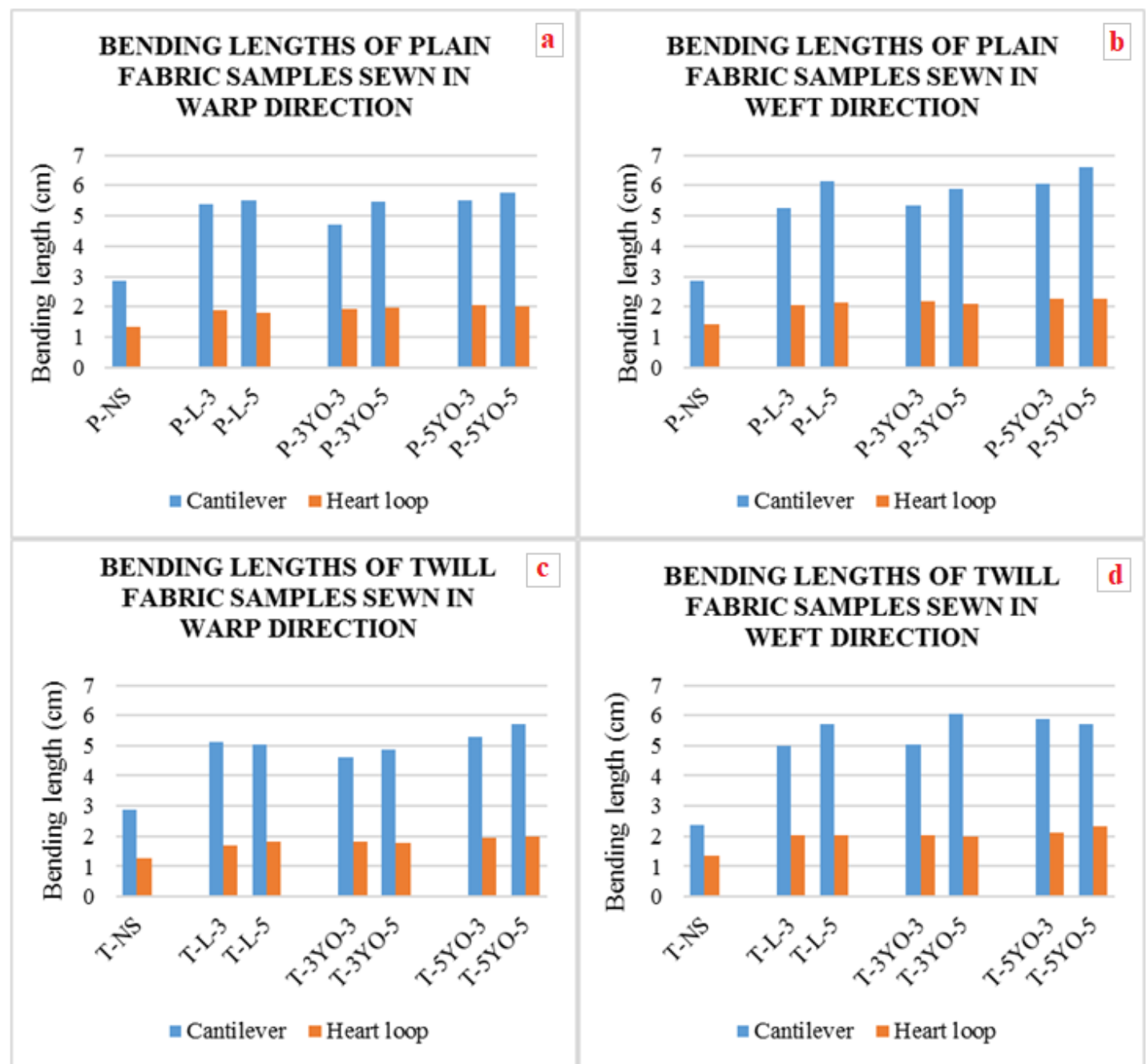

Figure 3. Bending lenghts of samples a) Plain fabric warp direction b) Plain fabric weft direction c) Twill fabric warp direction d) Twill fabric weft direction 
According to correlation analysis (Figure 4), there were moderate positive correlations between the bending lengths of samples obtained in cantilever and heart loop methods (In warp direction Spearman's rho: 0.652, and in weft direction Spearman's rho: 0.507). The correlations were statistically significant at the level of 0.01 .

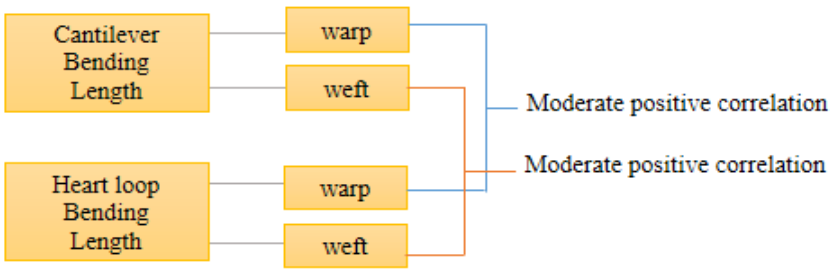

Figure 4. Bending length correlations

\subsection{Comparison of bending rigidity results}

Bending rigidity of samples were determined according to cantilever, heart loop and circular bend methods. Mean values and standard deviation values are tabulated in Table 4. In Figure 5, bending rigidity results are visualized according to fabric type and seam directions. The unit of bending rigidity obtained in cantilever method and heart loop method is different than the bending rigidity unit of circular bend method. Therefore, circular bend results should be read from the axis given in right part of the graphs.

According to test results, as for bending lengths, bending rigidity of unsewn samples were significantly lower when compared to sewn samples, for heart loop and cantilever methods (Sig. < 0.05). However, for circular bend method, any difference was not found between the bending rigidities of unsewn and sewn samples (Sig. values > 0.05). In addition, for circular bend method, any statistically significant difference was not found between bending rigidities of sewn samples dependent on the fabric type, stitch density and stitch type (Sig. values >0.05).

Bending rigidities of sewn samples with 5 stitch density were generally higher when compared to 3 stitch density, in cantilever method. The effect of stitch density on the bending rigidity was only significant for plain fabric samples sewn in weft direction (Sig. values < 0.05). A similar result was obtained by Gurarda (2008) for sewn plain fabrics tested in cantilever method [24]. The effect of stitching type was significant only for some of the sewn samples, for cantilever and heart loop methods. Similarly, Kara (2020) stated that overlock stitched samples, those were sewn in 5 different directions, showed higher bending rigidity for sewn plain fabrics according to heart loop method [23].

Correlation analysis results are summarized in Figure 6. According to correlation analysis, there is a moderate positive correlation between the bending rigidity results of cantilever and heart loop methods, (Spearmans' rho: 0.596), in the warp direction. The correlation is significant at 0.01 level. In warp direction, statistically significant correlations were not found between the circular test method and cantilever-heart loop methods. In weft direction, there was a low positive correlation between the bending rigidities of samples obtained by cantilever and heart loop methods (Spearmans' rho: 0.473 , significant at 0.01 level). In addition, in weft direction, a low positive correlation was found between the bending rigidities of cantilever and circular bending results (Spearmans' rho: 0.357, significant at 0.01 level). In the literature, a high correlation was found for the outputs of the heart loop and circular bend methods (Spearman's rho $>0.7$ ). But the tests were performed on net-like warp knitted fabrics [40]. The correlation differences are most probably caused by the sample sets, which were warp knitted fabrics for the mentioned study and sewn woven fabrics in this study.

Table 4. Bending rigidity results of cantilever, heart loop and circular bend methods

\begin{tabular}{|c|c|c|c|c|c|c|c|c|}
\hline \multirow{2}{*}{$\begin{array}{l}\text { Fabric } \\
\text { type }\end{array}$} & \multirow[t]{2}{*}{ Stitch type } & \multirow{2}{*}{$\begin{array}{l}\text { Sample } \\
\text { code }\end{array}$} & \multicolumn{2}{|c|}{$\begin{array}{l}\text { Cantilever Test Results } \\
\text { Bending Rigidity }(\mu \mathrm{J} / \mathrm{m})\end{array}$} & \multicolumn{2}{|c|}{$\begin{array}{l}\text { Heart Loop Test Results } \\
\text { Bending Rigidity }(\mu \mathrm{J} / \mathrm{m})\end{array}$} & \multicolumn{2}{|c|}{$\begin{array}{l}\text { Circular Bend Results } \\
\text { Bending Rigidity }(\mathrm{cN})\end{array}$} \\
\hline & & & $\begin{array}{l}\text { Warp Mean } \\
\text { (St. Dev.) }\end{array}$ & $\begin{array}{l}\text { Weft Mean } \\
\text { (St. Dev.) }\end{array}$ & $\begin{array}{c}\text { Warp Mean } \\
\text { (St. Dev.) }\end{array}$ & $\begin{array}{l}\text { Weft Mean } \\
\text { (St. Dev.) }\end{array}$ & $\begin{array}{c}\text { Warp Mean } \\
\text { (St. Dev.) }\end{array}$ & $\begin{array}{c}\text { Weft Mean } \\
\text { (St. Dev.) }\end{array}$ \\
\hline \multirow{7}{*}{$\begin{array}{l}\text { Plain } \\
\text { weave }\end{array}$} & & P-NS & $3.42(0.88)$ & $3.41(0.13)$ & $2.92(0.27)$ & $3.29(0.28)$ & $33.00(3.74)$ & $32.75(4.35)$ \\
\hline & \multirow{2}{*}{ Lock stitch } & P-L-3 & $22.57(1.67)$ & $21.04(3.51)$ & $7.72(0.67)$ & $10.03(1.95)$ & $31.20(2.49)$ & $33.00(1.41)$ \\
\hline & & P-L-5 & 24.25 (1.79) & $33.57(2.47)$ & $6.88(0.45)$ & $11.20(1.40)$ & $34.20(2.17)$ & $33.80(1.30)$ \\
\hline & \multirow{2}{*}{$\begin{array}{l}\text { 3-yarn } \\
\text { overlock stitch }\end{array}$} & P-3YO-3 & $15.36(1.80)$ & $22.05(2.37)$ & $8.42(0.38)$ & $12.02(1.71)$ & $31.40(4.16)$ & $34.20(4.49)$ \\
\hline & & P-3YO-5 & $23.84(1.33)$ & $29.62(2.00)$ & $8.85(1.15)$ & $10.55(0.90)$ & $35.20(1.92)$ & $35.00(2.74)$ \\
\hline & \multirow{2}{*}{$\begin{array}{l}\text { 5-yarn } \\
\text { overlock stitch }\end{array}$} & P-5YO-3 & $24.54(3.32)$ & $32.67(2.22)$ & $10.40(0.92)$ & $13.63(2.34)$ & $33.80(2.86)$ & $36.00(1.41)$ \\
\hline & & & $28.18(5.02)$ & $42.20(5.2$ & $9.74(0.84)$ & & $31.60(3.21)$ & \\
\hline \multirow{7}{*}{$\begin{array}{l}\text { Twill } \\
\text { weave }\end{array}$} & & T-NS & $3.97(0.31)$ & $2.24(0.13)$ & $2.59(0.27)$ & $3.19(0.26)$ & $33.80(2.2$ & $35.50(0.58)$ \\
\hline & \multirow{2}{*}{ Lock stitch } & T-L-3 & $22.09(1.48)$ & $20.55(3.06)$ & $6.54(0.34)$ & $10.77(0.22)$ & $38.00(1.58)$ & $37.20(2.77)$ \\
\hline & & T-L-5 & $21.13(2.49)$ & $30.815 .76)$ & $7.85(0.18)$ & $11.12(1.04)$ & $37.00(1.87)$ & $39.60(2.79)$ \\
\hline & \multirow{2}{*}{$\begin{array}{l}\text { 3-yarn } \\
\text { overlock stitch }\end{array}$} & T-3YO-3 & $16.47(2.96)$ & $21.07(3.40)$ & $7.87(0.80)$ & $11.37(1.15)$ & $34.00(3.87)$ & $39.75(2.87)$ \\
\hline & & T-3YO-5 & $19.25(1.38)$ & $36.66(2.86)$ & $7.61(0.84)$ & $10.15(0.76)$ & $38.80(2.68)$ & $41.00(2.16)$ \\
\hline & \multirow{2}{*}{$\begin{array}{l}\text { 5-yarn } \\
\text { overlock stitch }\end{array}$} & T-5YO-3 & $24.92(6.72)$ & $33.69(3.22)$ & $9.85(0.93)$ & $12.52(1.80)$ & $38.80(2.68)$ & $39.60(1.14)$ \\
\hline & & T-5YO-5 & $31.05(2.03)$ & $31.02(5.35)$ & $10.76(1.77)$ & $16.85(1.74)$ & $35.80(2.77)$ & $38.80(2.86)$ \\
\hline
\end{tabular}




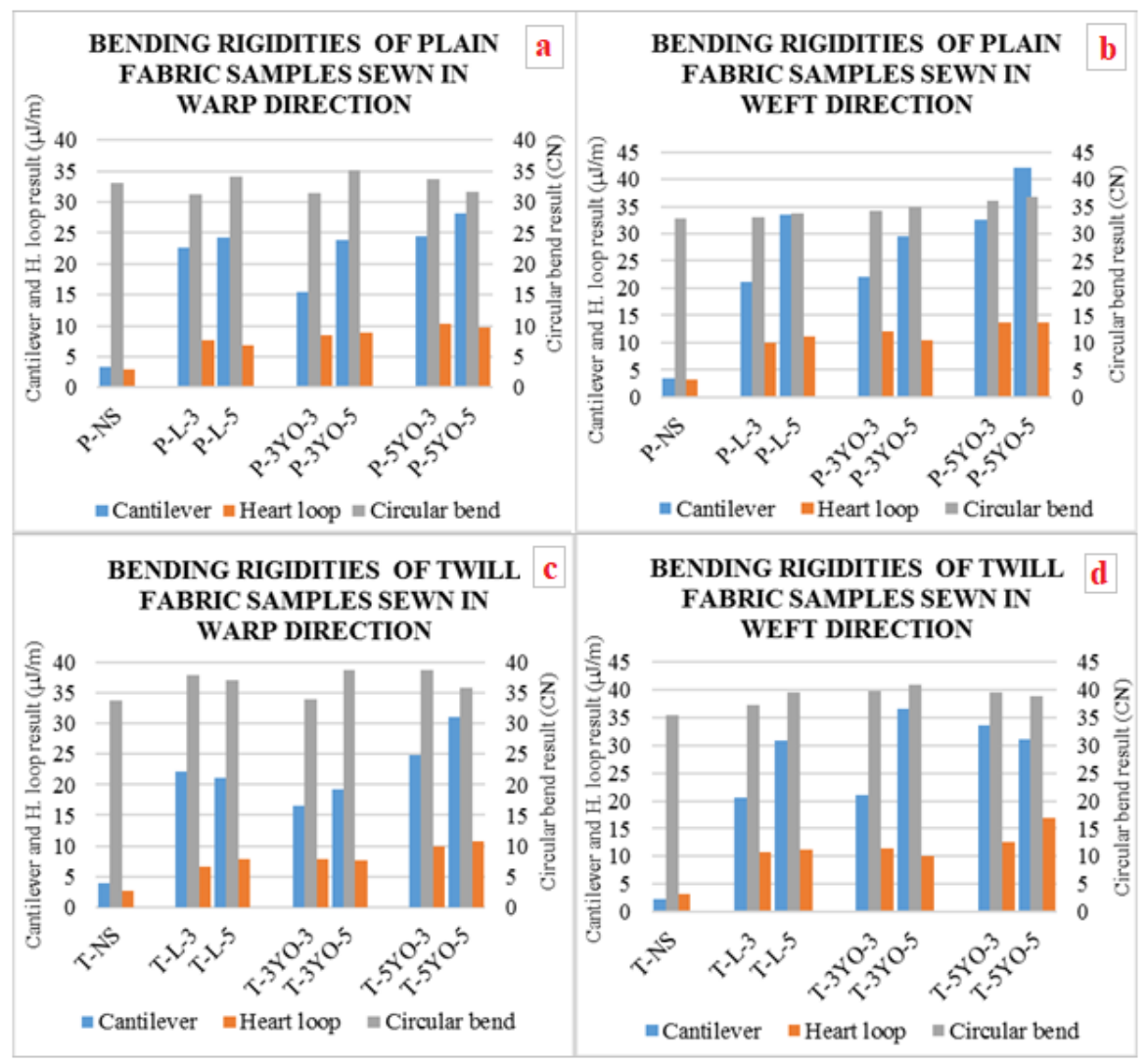

Figure 5. Bending rigidities of samples a) Plain fabric warp direction b) Plain fabric weft direction c) Twill fabric warp direction d) Twill fabric weft direction

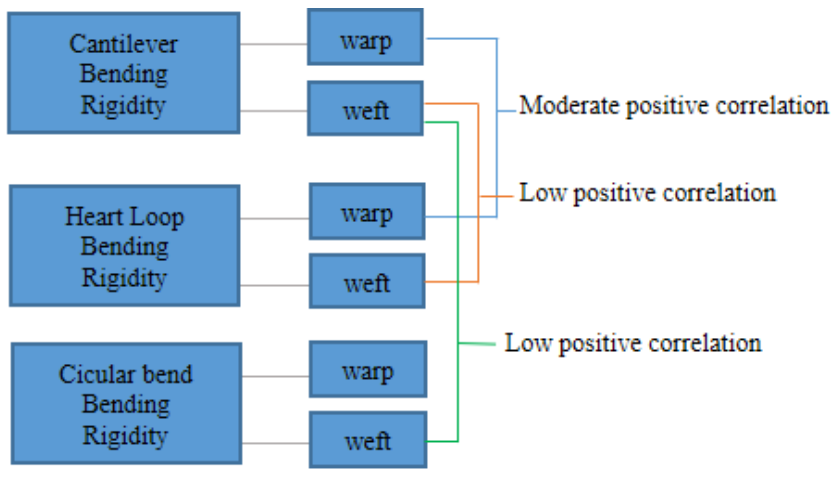

Figure 6. Bending rigidity correlations

\section{CONCLUSION}

In this study, the effects of different test methods on the bending length and bending rigidities of sewn samples were investigated. For this purpose, 3 simple and standard test methods; namely cantilever, heart loop and circular bend methods were used and compared. To examine the differences, a set of samples were prepared by using plain and twill PET fabrics, sewn with lock stitch, 3-yarn overlock stitch and 5-yarn overlock stitch with stitching densities of 3 stitches $/ \mathrm{cm}$ and 5 stitches $/ \mathrm{cm}$.

Statistical analysis showed that, in heart loop and circular bend methods, significant effects of stitch densities were not detected on the bending rigidities, for both warp and weft directions. Similarly, for the selected sample set and stitch types, significant effects of stitch types were not detected for most of the samples, in all 3 testing methods. The differences were mostly significant for 5-yarn overlock stitched samples, which showed higher stiffness. It was interesting that, in circular bend method, any statistically significant difference could not be detected for any type of samples, including unsewn ones.

Correlation analysis results showed that, there are moderate positive correlations between the bending lengths of cantilever and heart loop methods, in both warp and weft directions. For bending rigidities, cantilever test method possessed moderate positive correlation with heart loop method in warp direction and low positive correlations with heart loop and circular bend methods in weft direction. For the designed sewn sample set, any statistically significant relationship was not detected between heart loop and circular bend methods, for sewn samples.

As a conclusion, it can be inferred that, results of selected test methods do not fit highly, for sewn fabrics. Cantilever and heart loop methods are better in correlation but, in spite of being a standard test method, circular bend method does not correlate well with other test methods for bending rigidity of sewn samples. This can be related to the different testing approaches and sample sizes in these three methods. 
But it must also be considered that, this study is limited with the designed sample set. In the further studies, the relationship of bending rigidity and bending lengths of samples can be examined with different types of fabrics and seaming techniques. The results of this study is expected to contribute to the researches in this field and may be benefical for the quality control tests of ready-wear companies.

\section{REFERENCES}

1. Kurumer G. 2012. Konfeksiyon uretimi ve teknolojisi (2 ${ }^{\text {nd }}$ Press). Izmir: Printer Ofset Matbaacilık.

2. Jones I, Stylios GK. 2013. Joining textiles: Principles and applications. Cambridge: Woodhead Publishing Limited.

3. Fan J, Hunter L. 2009. Engineering apparel fabrics and garments. Cambridge: Woodhead Publishing Limited.

4. Namiranian R, Shaikhzadeh Najar S, Etrati SM, Manich AM. 2014 Seam slippage and seam strength behavior of elastic woven fabrics under static loading. Indian Journal of Fibre \& Textile Research 39(3), 221-229.

5. Choudhary AK, Goel A. 2013. Effect of some fabric and sewing conditions on apparel seam characteristics. Journal of Textiles 2013, $1-7$.

6. Gurarda A. 2008. Investigation of the seam performance of PET/nylon-elastane woven fabrics. Textile Research Journal 78(1), 21-27.

7. Bharani M, Shiyamaladevi PSS, Mahendra Gowda RV. 2012. Characterization of seam strength and seam slippage on cotton fabric with woven structures and finish. Research Journal of Engineering Sciences 1(2), 41-50.

8. Sular V, Mesegul C, Kefsiz H, Seki Y. 2015. A comparative study on seam performance of cotton and polyester woven fabrics. The Journal of the Textile Institute 106(1), 19-30.

9. Citoglu F, Kaya G. 2011. Dikis iplik ozelliklerinin ve dikis sıkliklarinin farklı dikis acilarında dikis mukavemeti uzerine etkileri. Tekstil ve Konfeksiyon 21(2), 182-188.

10. Xin LU. 2010. Effect of sewing form and parameters on seam strength of silk fabric. Shanghai Textile Science \& Technology 5, 17.

11. Ozdemir H, Yavuzkasap D. 2012. The effects of yarn and fabric structural parameters on the seam slippage, abrasion and pilling properties of double woven upholstery fabrics. Industria Textila 63(6), 307-314.

12. Yeşilpınar S, Bahar S. 2007. The effect of sewing and washing processes on the seam strength of denim trousers. AATCC review 7(10), 27-31.

13. Yeşilpınar S. 2006. Analysis of the performance of sewing threads manufactured from conventional and compact ring-spun yarns. Fibres \& Textiles in Eastern Europe 14(2), 20-23.

14. Gribaa S, Ben Amar S, Dogui A. 2006. Influence of sewing parameters upon the tensile behavior of textile assembly. International Journal of Clothing Science and Technology, 18 (4), 235-246.

15. Chowdhary U, Poynor D. 2006. Impact of stitch density on seam strength, seam elongation, and seam efficiency. International Journal of Consumer Studies 30(6), 561-568.

16. Tarafder N, Karmakar R, Mondal M. 2007. The effect of stitch density on seam performance of garments stitched from plain and twill fabrics. Man-Made Textiles in India 50(8), 298-302.

17. Mukhopadhyay A, Sikka M, Karmakar AK. 2004. Impact of laundering on the seam tensile properties of suiting fabric.

\section{Acknowledgement}

Author thanks the statistician and data scienstist Sibel ALKAN for her help in statistical analysis. The circular bending tests were performed in Pamukkale University, Textile Engineering Department (Denizli, Turkey). The author would like to thank the Head of the Department for providing the use of test device.

International Journal of Clothing Science and Technology 16(4), 394-403.

18. Ünal BZ, Baykal PD. 2018. Determining the effects of different sewing threads and different washing types on fabric tensile and sewing strength properties. Tekstil ve Konfeksiyon, 28(1), 34-42.

19. Islam M, Sarker TR, Islam MJ, Siddque N. 2019. Comparative analysis of seam strength, seam slippage and seam efficiency of lapped seam and edge neatening seam. Trends in Textile Engineering \& Fashion Technology 5(5), 665-670.

20. Ateş M, Gürarda A, Çeven EK. 2019. Investigation of seam performance of chain stitch and lockstitch used in denim trousers. Tekstil ve Mühendis 26(115), 263-270.

21. Khan MR, Rasel M, Das D. 2020. Effect of thread count and stitch density (SPI) on 2/1 twill woven fabric. International Journal of Science and Business 4(3), 37-45.

22. Fairhurst C. 2008. Advances in apparel production. Cambridge: Woodhead Publishing Limited.

23. Kara S. 2020. Comparison of sewn fabric bending rigidities obtained by heart loop method: Effects of different stitching types and seam directions. Industria Textila 71(2), 105-111.

24. Gurarda A. 2009. The effects of seam parameters on the stiffness of woven fabrics. Tekstil ve Konfeksiyon 19(3), 242-247.

25. Megeid ZA, Ezzat MM, Elzaki GM. 2016. Studying the bending stiffness of polyester/linen fabric seams with different structures. International Journal of ChemTech Research 9(4), 01-06.

26. Hu J. Chung S. 2000. Bending behavior of woven fabrics with vertical seams. Textile Research Journal 70(2), 148-153.

27. Chung S, Hu J, Lo M. 1999. Effect of seam allowance of a plain seam on bending of woven fabrics. Research Journal of Textile and Apparel 3(1), 54-64.

28. Mahar TJ, Ajiki I, Postle R. 1989. Fabric mechanical and physical properties relevant to clothing manufacture- Part 2: Structural balance, breaking elongation and curvature of seams. International Journal of Clothing Science and Technology 1(2), 5-10.

29. Macit AȘ, Tiber B. 2017. Evaluation of bending rigidity behaviour of ultrasonic seaming on woven fabrics. IOP Conference Series: Materials Science and Engineering 254(13), 132002, 1-6.

30. Gupta BS, Leek FJ, Barker RL, Buchanan DR, Little TJ. 1992. Directional variations in fabric properties and seam quality. International Journal of Clothing Science and Technology 4(2/3), 7178.

31. Ghosh, TK, Zhou N. 2003. Characterization of fabric bending behavior: A review of measurement principles. Indian Jounal of Fibre and Textile Research 28, 471-476.

32. Sanad RA, Cassidy T. 2015. Fabric objective measurement and drape. Textile Progress 47(4), 317-406.

33. Kayseri GÖ, Özdil N, Mengüç GS. 2012. Sensorial comfort of textile materials. In HY Jeon (Ed.), Woven fabrics. Croatia: Intech, 235-66. 
34. Abbott NJ. 1951. The measurement of stiffness in textile fabrics. Textile Research Journal 21(6), 435-441.

35. Hynek WJ, Winston G. 1953. A comparative study of the Tinius Olsen and Peirce stiffness testers. Textile Research Journal 23(10), 743-748.

36. Takatera M, Shinohara A. 1996. An analysis to compare conventional methods for estimating bending rigidity of fabrics. Journal of the Textile Machinery Society of Japan, 42(3-4), 86-92.

37. Naujokaitytė L, Strazdienè E, Fridrichova L. 2007. Comparative analysis of fabrics' bending behavior testing methods. Tekstil: Journal of Textile \& Clothing Technology, 56(6), 343-349.

38. Harrabi L, Dolez PI, Vu-Khanh T, Lara J, Tremblay G, Nadeau S, Larivière C. 2008. Characterization of protective gloves stiffness: Development of a multidirectional deformation test method. Safety Science 46(7), 1025-1036.

39. Sun MN. 2008. A new tester and method for measuring fabric stiffness and drape. Textile Research Journal 78(9), 761-770.

40. Goetzendorf-Grabowska B, Karaszewska A, Vlasenko VI, Arabuli AT. 2014. Bending stiffness of knitted fabrics-comparison of test methods. Fibres \& Textiles in Eastern Europe 22, 1(103), 43-50.
41. Musa ABH, Malengier B, Van Langenhove L, Stevens C. 2017. The reliability of the newly developed bending tester for the measurement of flexural rigidity of textile materials. IOP Conference Series. Materials Science and Engineering 254(14), 142004, 1-6.

42. Plaut RH. 2020. Determining effective bending stiffness of fabrics and other materials from tests involving an added weight. Textile Research Journal 90(1), 101-109.

43. Peirce FT. 1930. The "handle" of cloth as a measurable quantity. Journal of the Textile Institute Transactions 21(9), T377-T416.

44. ASTM D1388-18. 2018. Standard test method for stiffness of fabrics. West Conshohocken: ASTM International.

45. Hu J. 2004. Structure and mechanics of woven fabrics. Cambridge: Woodhead Publishing Limited.

46. ASTM D4032 - 08. 2016. Standard Test Method for Stiffness of Fabric by the Circular Bend Procedure. Cambridge: Woodhead Publishing Limited. 